\title{
EFFECT OF DEVERNALIZATION ON THE TRANSITION FROM VEGETATIVE TO PREFLORAL PHASE OF THE BROCCOLI (Brassica oleracea var. italica cv. 'Fiesta') SHOOT MERISTEM
}

\author{
${ }^{1}$ Elżbieta Zenkteler, ${ }^{2}$ Sławomir Samardakiewicz, ${ }^{3}$ Alina Kałużewicz, ${ }^{3}$ Mikołaj Knaflewski
}

\author{
${ }^{1}$ Department of General Botany, Institute of Experimental Biology, \\ ${ }^{2}$ Laboratory of Electron and Confocal Microscopy, Faculty of Biology, A. Mickiewicz University, \\ 61-614 Poznań, Umultowska 89, Poland \\ ${ }^{3}$ Department of Vegetable Crops, Nature University, 60-594 Poznań, Dąbrowskiego 159,Poland, \\ e-mail: elzbieta.zenkteler@amu.edu.pl
}

Received: 08.12.2011

\section{Abstract}

The morphological and histological changes which occur in the cold-induced apical meristem of broccoli ( $B$. oleracea var. italica $\mathrm{cv}$. 'Fiesta') during transition from the vegetative to the generative phase have been demonstrated in our previous investigations. Now, a light microscopic study on the micromorphological parameters of the tunica and corpus of the meristem was undertaken to ascertain their association with devernalisation. Changes in the apex of broccoli seedlings grown for 26 days at $24^{\circ} \mathrm{C}$, succeeded by 35 days of cold treatment $\left(16^{\circ} \mathrm{C}\right.$ - vernalization) followed by 14 days of warm treatment $\left(24^{\circ} \mathrm{C}\right.$ - devernalization), were studied and described. Microscopic analysis according to the new method of slide preparation showed cytohistological zonation and the spatial distribution of cells in the central and peripheral zones of the broccoli shoot meristem more precisely than possible hitherto. Comparison between subsequent stages of meristem reorganization after devernalization revealed variation in the structure of the apex during its transition to the evocation phase of flowering. The results of measurements show that the tunica width changes irregularly, increasing from its minimum value $(112.39 \pm 5.78 \mu \mathrm{m})$ through the medium one to the maximum values $(260.32 \pm 2.50)$, to decrease again, while its height increased and decreased sinusoidally from its minimum value $(21.52 \pm 4.30 \mu \mathrm{m})$ to the maximum one $(76.98 \pm 7.44 \mu \mathrm{m})$ and then decreasing again to the minimum value $(21.52 \pm 4.30)$. The stratification of the tunica as well as its width and height revealed relatively low variation within the analyzed time. These structural traits correlated with cold/warm treatments may be further utilized in the broccoli breeding programme against developmental disturbances.

Key words: shoot apical meristem - SAM, broccoli cv. 'Fiesta', devernalization, transition to flowering

\section{INTRODUCTION}

Data concerning the cytohistological zonation of the shoot meristem are well documented in the literature (Hejnowicz, 2002). In shoot apices of angiosperms, the tunica-corpus concept and the cytohistological zonation concept (the central zone, the flanking zone, and the rib meristem zone) are compatible, although based on entirely different principles. In the tunica-corpus concept the distinction is based mostly on the plane of cell division, while in the zonation concept the separation of zones is based on the different cytological appearance of cells (C ors on and $\mathrm{G}$ if f o r d 1969). The zonation of the apical meristem was gradually lost as the plants became older (it is still evident in $5 \mathrm{~cm}$ high seedlings but later, when they reach $25-50 \mathrm{~cm}$, the zonation disappears). Some authors have explained the disappearance of zonation in older plants as resulting from the transition to the intermediate phase during which the meristem can no longer be receptive due to the increase of mitotic activity in the axial region (C u t te $r, 1970)$.

Recently, the zonation of the shoot meristem have been described by cellular, functional and genetic parameters concerning the spatial distance between slower dividing initials of the central zone and the faster dividing peripheral, organogenic zone ( $\mathrm{S} \mathrm{c} \mathrm{o-}$ fi eld and Murray a, 2006; Ve it , 2006).

The transition from the vegetative to the reproductive phase during broccoli shoot apex development is a prominent change in the plant life cycle, strongly dependent on multiple environmental factors, i.e. day length, light intensity, temperature (F u j i m e 
and Okuda, 1994; Fujime and Okuda, 1996; Mourao and Handley, 1998). Temperature dependence was the factor which synchronized broccoli curd induction in a large population of seedlings, and this was especially induced by cold treatment. It was found that the optimum temperature for broccoli vernalisation was $16^{\circ} \mathrm{C}$ (W u r r et al. 1995). Under cold treatment, the induction of flowering may be applied to three different stages of plant development: only for seeds, for juvenile seedlings, or mature plants. Vernalization depends not only on genotype, but also on the seedling stage, i.e. in Brassica oleracea var. gemmifera (brussels sprout) the effectiveness of cold treatment applies only to nine-week-old seedlings, while in Brassica oleracea var. botrytis (cauliflower) young seedlings of no more than two weeks were the most receptive (B e s n ard - W i b a u t, 1977).

Generative transition of the shoot apex of Brassica oleracea var. italica cv. 'Fiesta' to flowering under thermal time requirements was investigated using histological criteria of the shape and size of the meristem (K a ł u żew i c z et al. 2002). In order to apply micrometric analysis, the authors indicated four developmental phases of broccoli meristem: vegetative, evocation, early generative and late generative, which followed fluently one after another. They also stated that "the time from the planting out of broccoli seedlings cv. 'Fiesta' to the evocation phase was constant and amounted to 18 days, but the time from sowing to planting out lasted much longer and was variable (29 to 43 days)" (K a ł u ż e w i c z et al. 2002).

Predicting broccoli development arising from variable climatic conditions is of high practical importance. A sudden increase of temperature can modify the floral initiation response in broccoli ( $\mathrm{T}$ a n et al. 2000). Above $22^{\circ} \mathrm{C}$ (W u r r et al. 1995) or $24-27^{\circ} \mathrm{C}$ (B j ö r k m a n and P e a r s o n , 1998) no vernalization effect was found. According to Fontes et al. (1967), a sudden increase in temperature to $22-26^{\circ} \mathrm{C}$ after cold treatment has a devernalization effect. However, it has not yet been determined for how long and at what developmental phase warm treatment will act to reverse vernalization.

The aim of our experiment was to determine changes in the developmental phases after devernalization of the shoot apex of the broccoli cv. 'Fiesta' during transition from the vegetative to the generative phase of inflorescence development.

\section{MATERIALS AND METHODS}

Seeds of broccoli (Brassica oleracea var. itali$c a$ cv. 'Fiesta') were sown on the $23^{\text {rd }}$ of March 2006. After six days the seedlings were potted in peat moss with the addition of lime ( $\mathrm{pH}$ 5.6). Until the five-leaf stage, the seedlings were grown in a growth chamber at $24^{\circ} \mathrm{C}$ (to April $24^{\text {th }}$ ) The temperature was then reduced to $16^{\circ} \mathrm{C}$ on May $27^{\text {th }}$. After vernalization, the seedlings were treated at $24^{\circ} \mathrm{C}$ (devernalization) for a period of 14 days and were then planted out. During the last period (14 days), 6 shoot apical meristems (SAM) of broccoli were collected (every 2 days) from the actively growing seedlings at regular time intervals starting on May $27^{\text {th }}$ and ending on June $10^{\text {th }}$, 2006. All samples were fixed in FAA (formalin-acetic-acid-ethanol), and then dehydrated and after staining with $0.1 \%$ aqueous solution of Eosin B (Sigma) they were embedded in paraplast. Serial longitudinal sections, $7-10 \mu \mathrm{m}$ in thickness, were cut. The staining method with safranin-fast green had been utilized previously (K a ł u ż e w i c z et al. 2002), but at present only an analysis of paraplast sections without the staining procedure was applied (Samardakiewicz, personal communication). Sections were preserved without any deformations due to the dehydration procedure. Eosin B, as a fluorescent dye, stains the cell walls and makes it possible to register shoot meristem images with a Zeiss confocal microscope LMS 510, using laser light of $514 \mathrm{~nm}$ and HFT 458/514 I LP 530 filters.

Size determinations of the shoot apex zones were carried out on median longitudinal sections. Width and height micrometric measurements of the tunica of the shoot apex from each time of meristem isolation were taken in reference to a line established from the bases of the youngest leaf primordia in the section and perpendicular to the axis of the stem (Fig. 1). The accuracy of the width and height measurements of the tunica was dependent upon their cytological distinctiveness from the surrounding zones. Samples were statistically analysed employing ANOVA to ascertain the significance of tunica characteristics.

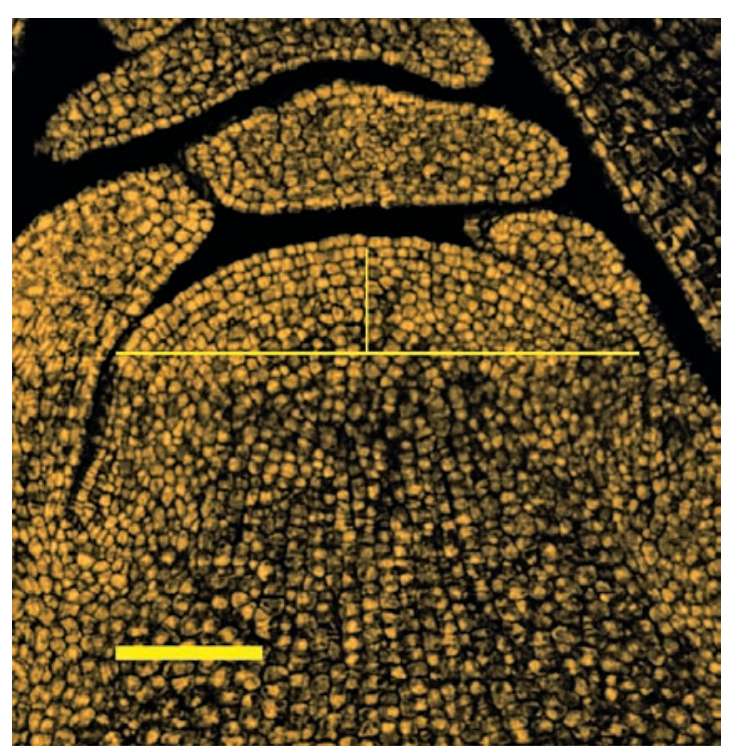

Fig. 1. Median longitudinal section of a SAM (shoot apical meristem) of broccoli. Pattern of measurements of height and width of the tunica. Bar $100 \mu \mathrm{m}$ 


\section{RESULTS}

Shoot meristems of broccoli during synchronous thermal induction to flowering show differences of their histological characters (e.g. cell size, shape, and stainability).

\section{Vegetative apex}

The apical meristem of broccoli was relatively small ( 0.3 to $0.5 \mathrm{~mm}$ in diameter) and dome-shaped and it had a tunica-corpus organization. The zonation of shoot meristems (central, peripheral, and sub-apical) was present in varying degrees in all sections of one specimen. Temporary fluctuations of its shape occurred as the apex periodically increased in diameter and became flattened during leaf primordia initiations. No differences in the pattern of zonation could be observed between maximal and minimal areas (plastochronic phases) of the shoot apex. As vegetative growth progressed and new leaf primordia were cut off, the buttress appeared to flatten out slightly. Although this feature was observed frequently, it could not be associated with floral induction only. In the vegetative apex, the mitotic activity was higher in the peripheral zones than in the central ones. Topographically, the shoot apices (control) varied from dome-shaped ones at the beginning of observations, while by the end of the experiment they had become broad and flattened (Fig. $2 \mathrm{~A}_{1}-\mathrm{A}_{6}$ ).

\section{Characteristics of the tunica}

Stratification on the vegetative tunica consists of 4 to 6 layers of cells with anticlinal divisions. Such a large number of cell layers has not been previously reported for the tunica of broccoli owing to the application of differing methods of fixation and section dehydration. In most samples of multiseriate tunica, the cells of the $\mathrm{L}_{1}-\mathrm{L}_{3}$ layer were the same size as the cells of the $\mathrm{L}_{4}$ and remaining layers, which were somewhat irregular in shape and in arrangement. There were significant differences between the parameters of tunica height in meristems collected at the end of May compared to the beginning of June (Fig. 5). After devernalization treatment, the tunica height started to increase from $21.52 \pm 4.29 \mu \mathrm{m}$ to $76.98 \pm 7.44 \mu \mathrm{m}$ and to decrease from $76.97 \pm 7.44 \mu \mathrm{m}$ down to $23.52 \pm$ $1.90 \mu \mathrm{m}$, while the width alternatively increased or decreased (Figs 3 B-E and 4 F-I, Fig. 5). The anatomical structure of the tunica reflected a delay in their flower morphogenesis. In the prefloral phase, the apex contained only 2-3 layers of tunica (Fig. $2 \mathrm{~F}$ and Fig. 4 I).

\section{Characteristics of the corpus}

The corpus had a central and peripheral zone and poorly-defined procambium strands composed of periclinally divided cells (Fig. 4. H). The corpus tends to form a radiating pattern from the central to peripheral zones. Cells basal to the central zone were aligned parallel to the shoot axis. Cytologically definable central cells were approximately 1.5 times larger than in the tunica, acropetally vacuolated, and arranged less regularly than those of surrounding cells. These cells tend to elongation which causes elongation of the apical internodes (bolting). The change in cell shape is an early event of the floral transition preceding the initiation of floral bract primordia. During transition to the evocation phase, the cytohistological zonation of broccoli apices did not become rearranged significantly (Fig. $2 \mathrm{~A}_{1}-\mathrm{A}_{6}$, control). Anatomical analysis revealed that despite devernalization the corpus belonged to the least changeable area of the apical meristem.

\section{Prefloral apex}

In studying the increasing rate of cell division that occurs in the tunica and elongation of the axis in the corpus of the broccoli apex, we presumed that interruption in the transition to flowering induced by an increase of temperature during devernalization had begun on the $2^{\text {nd }}$ of June (Fig. 5). Also, changes in the plane of cell division modify the dimension of the width of the meristem which increased/decreased alternately (Fig. 3). Instead, the first indication of floral evocation (control) was evident when the surface of the apex enlarged (between June $2^{\text {nd }}-6^{\text {th }}$ ) and its width increased when compared to the vegetative apex (Fig. $2 \mathrm{~A}_{1}-\mathrm{A}_{6}$ ). The results of micrometric measurement of devernalized apices revealed a significant fluctuation of their width parameters after thermal stimulation. The width of the vegetative apex varied from $112.39 \pm 2.50$ through $260.32 \pm 18.16$ to $211.22 \pm 12.53 \mu \mathrm{m}$, respectively (Fig. 5). 

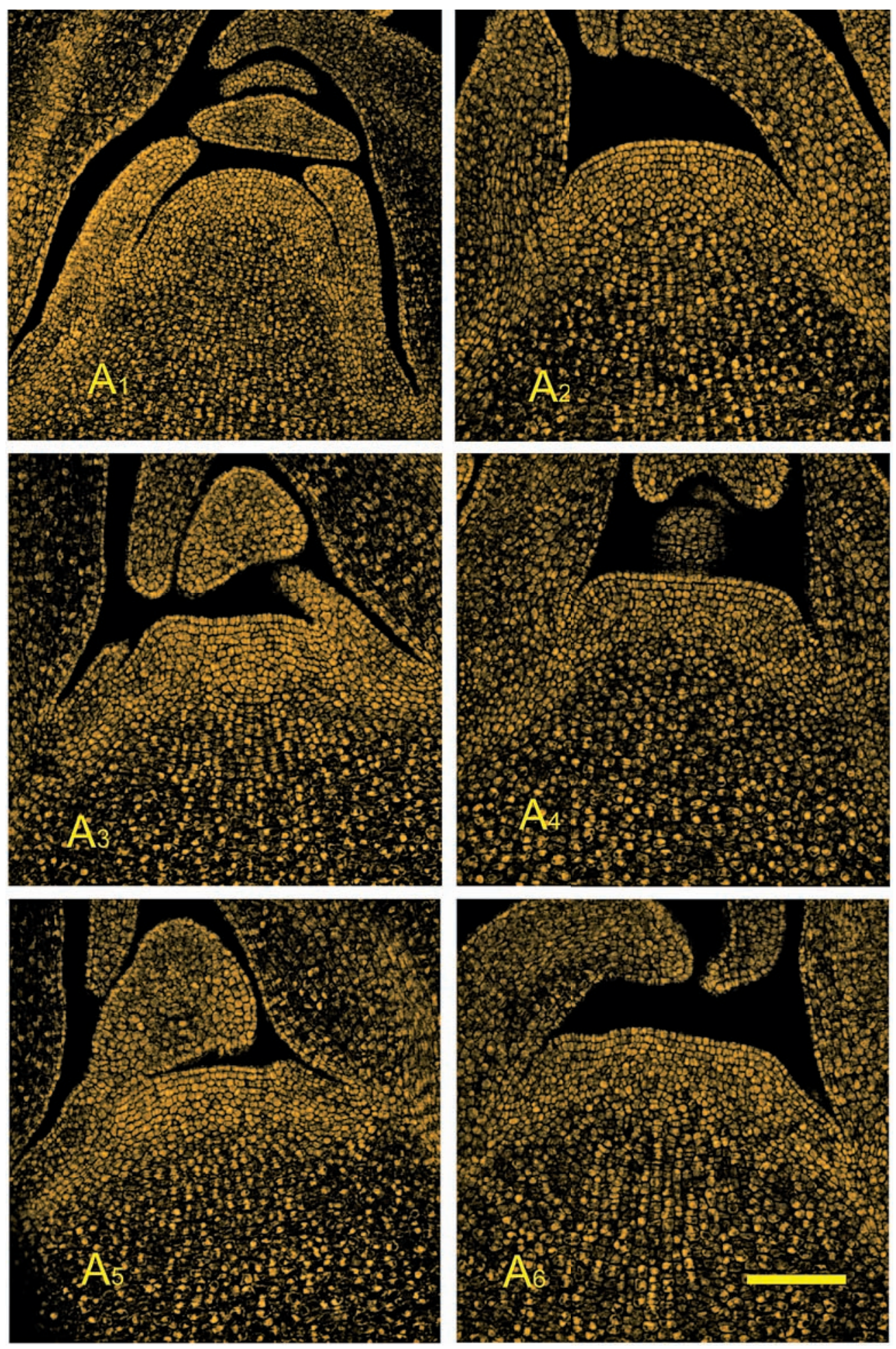

Fig. 2. A1-A6 Comparison of tunica width and height during transition from vegetative to evocation phase (control - without devernalization 24. 04 - 27. 05.06). Bar $100 \mu \mathrm{m}$ 

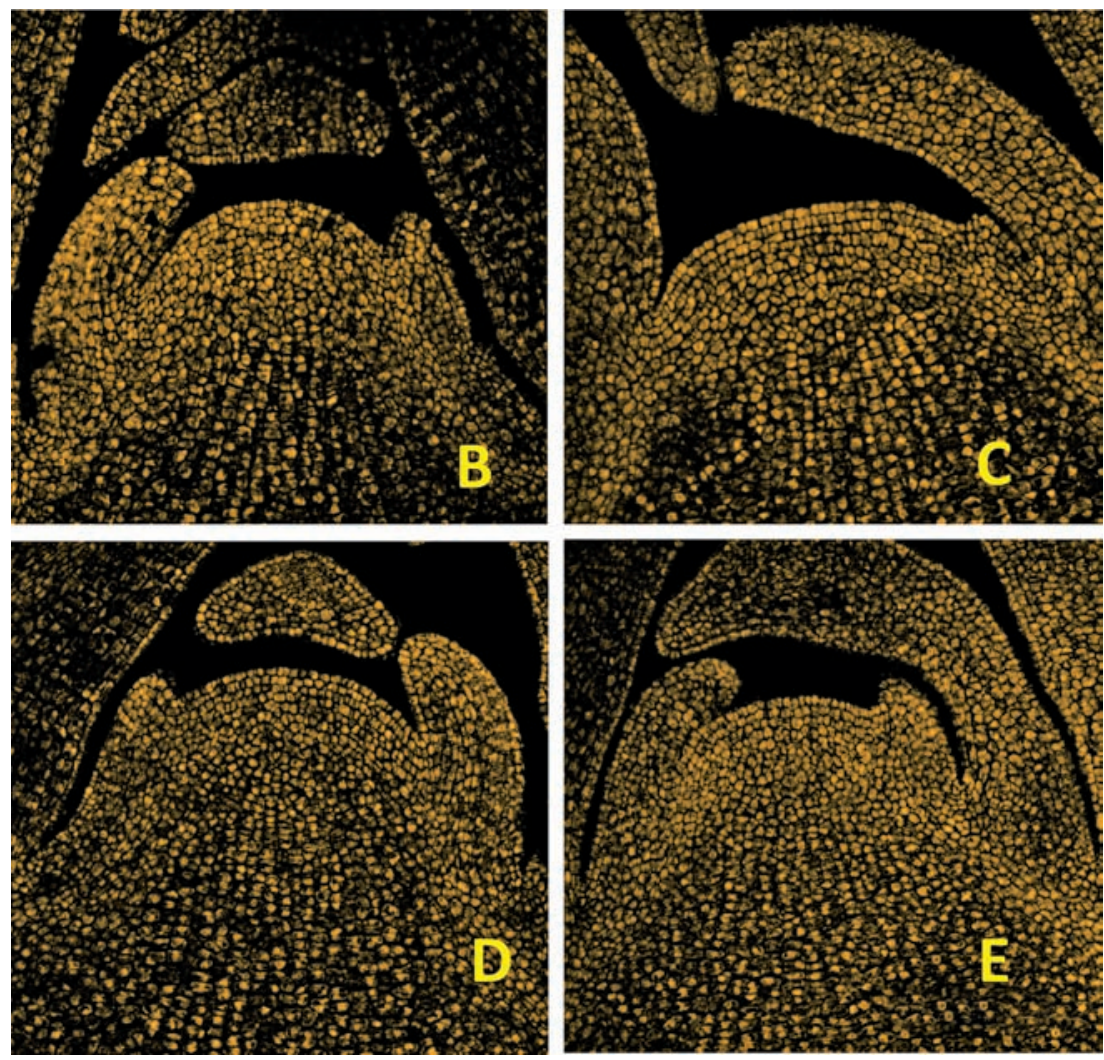

Fig. 3. B-E. Disturbances of tunica width and height after devernalization treatment ( from May 27th to June 2nd).
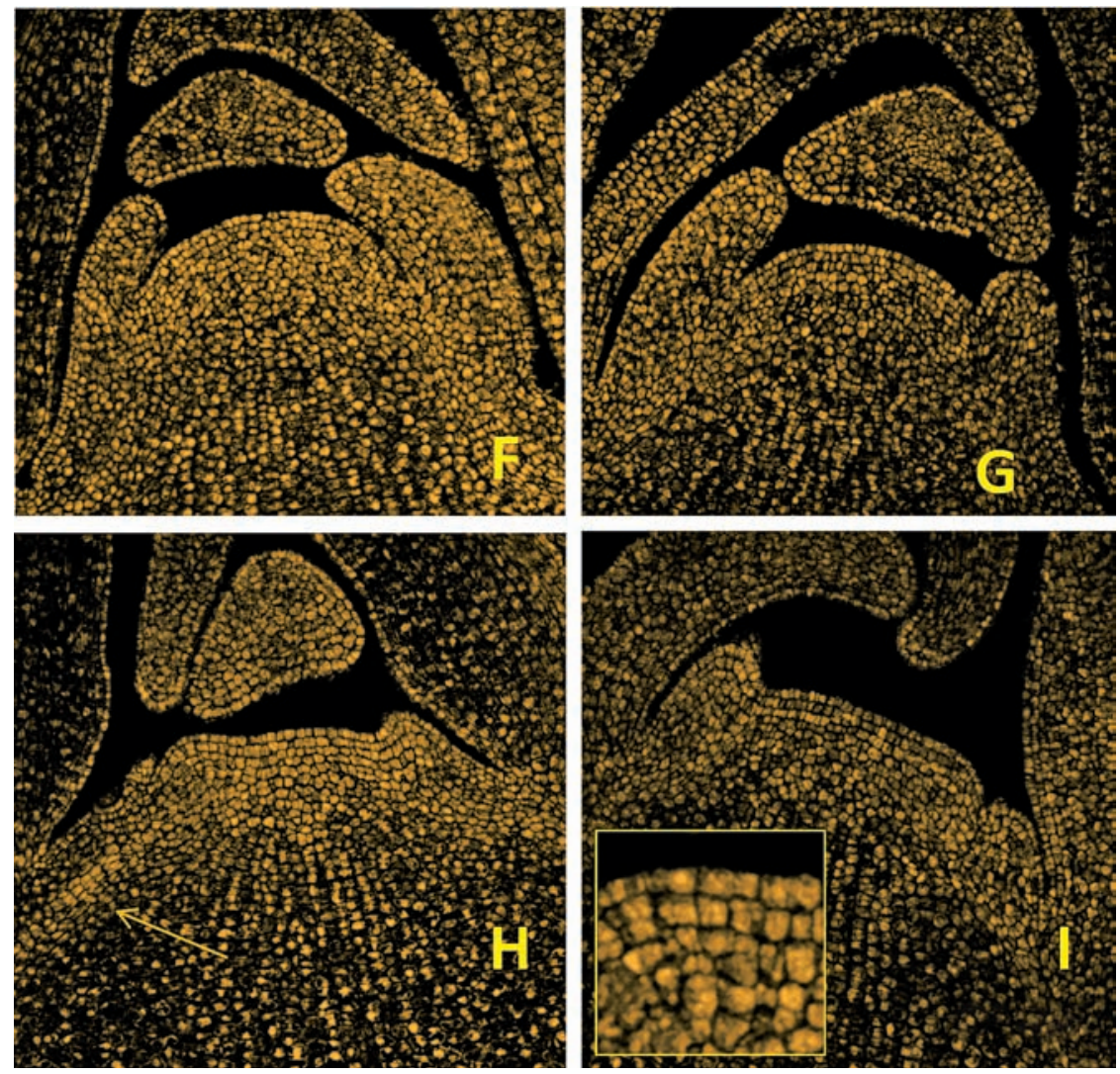

Fig. 4. F-I. Developmental sequences of shoot meristems of broccoli after devernalization (from June 4th to June 10th). H. - Procambium strand - arrow. I. - Prefloral tunica contains 2-3 layers of cells. Bar $100 \mu \mathrm{m}$ 


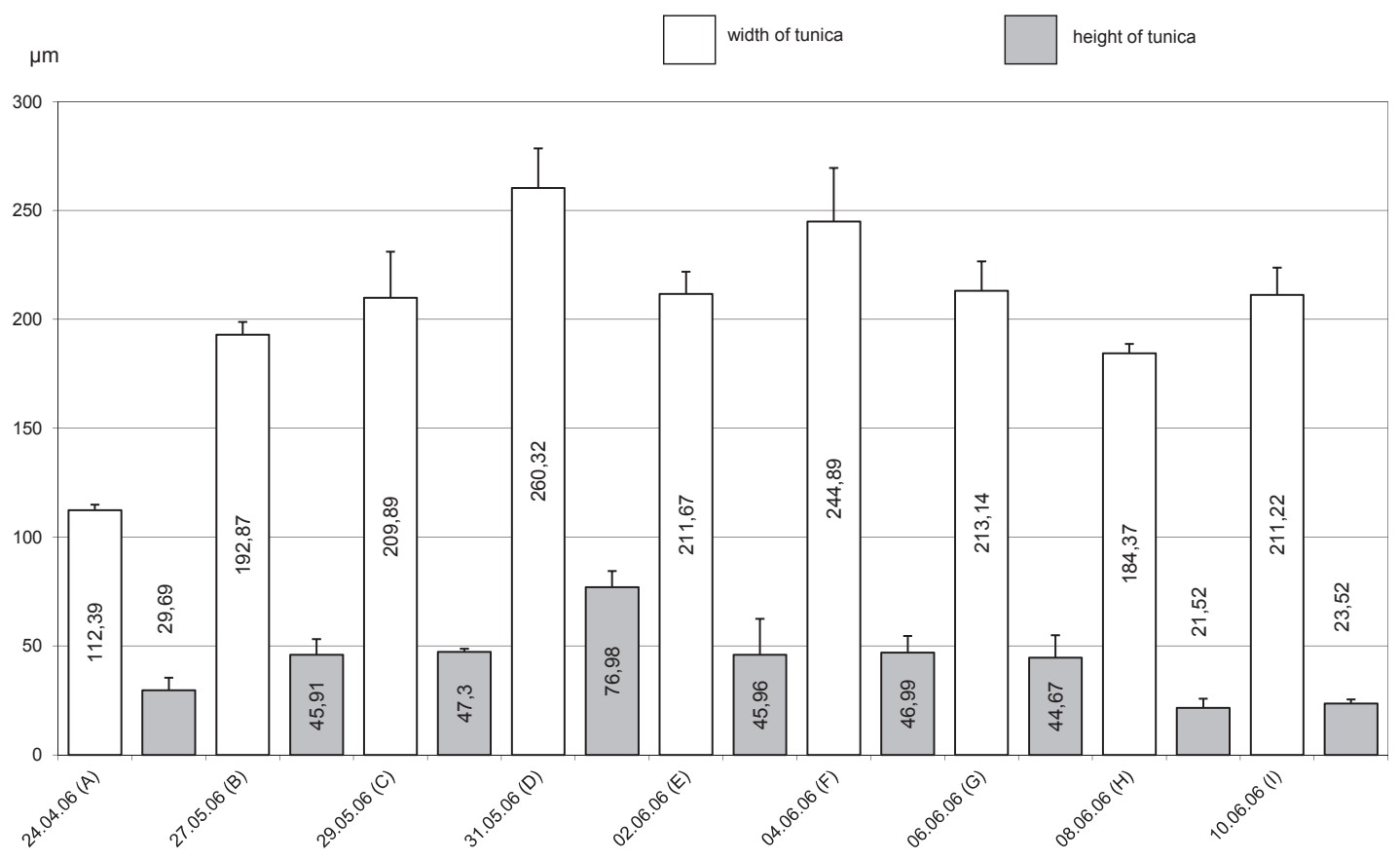

Fig. 5 Changes in the width $(184-260.32 \mu \mathrm{m})$ and height $(76-98-23.52 \mu \mathrm{m})$ of the tunica during transition from vegetative to generative phase of broccoli shoot apical meristem.

\section{DISCUSSION}

Plants are capable of flowering if subjected to correct floral inductive conditions. In some species flowering does not occur until a certain number of internodes and leaves are developed. However, the relationship between total leaf number and response to temperature by floral initiation of cv. 'Fiesta' is not linear ( $\mathrm{T}$ a $\mathrm{n}$ et al. 2000). The promotion of flowering by low temperature (vernalization) occurs only if mitosis takes place during cold treatment ( $\mathrm{Cu}$ t t e r 1970).

Variable climatic conditions could modify the crop of broccoli curds due to sudden changes of temperature during seedling development. The effect of high temperature on young plants modifies floral primordia formation and delays curd harvest maturity $(\mathrm{F} \mathrm{u} \mathrm{j} \mathrm{i} \mathrm{m} \mathrm{e}$ and Okuda 1996).

As a result of previous investigations, the moment of flower evocation was considered to be when the meristem started to broaden and flatten at the buttress surface. The measurements revealed that during the evocation phase the mean tunica width of cv. 'Fiesta' was found to be 241 to $375 \mu \mathrm{m}$ (K ałużewicz et al. 2002). In our recent analysis (after devernalization), the phase of flower evocation does not occur as early as in the control experiment (with vernalization only). The effects of temperature modify flower primordia initiation responses in broccoli. Plants grown at $16^{\circ} \mathrm{C}$ formed floral primordia 1 week earlier than those not vernalized (F u j i m e et al. 1988). In our experiment, broccoli seedlings suddenly subjected to transfer from inductive to non-inductive conditions of temperature regime exhibited slow progress to the floral state. The time of flower evocation was delayed by disturbances which were indicated between the $2^{\text {nd }}$ and the $6^{\text {th }}$ of June 2006. The measurement of the size of the tunica was applied in order to provide data to make comparisons between subsequent developmental phases of the shoot apex of broccoli and to make it easier to predict harvest maturity. However, it became clear that these measurements could not be universally compared due to various apical shapes dependent on the position of the leaf primordia. During our investigations the development of the shoot apex was followed by evocation until the very early generative phase, so we distinguished only the prefloral phase. This is due to fact that histological observation was always static and fragmentary in character. A typical prefloral stage was recognized in many species (e.g. broccoli) and characterized by the distribution of RNA and protein between the axial and peripheral cells, which may indicate that the entire apex is involved in inflorescence production (C o r s o n and $\mathrm{G}$ i f f o r d , 1969). The transition of calabrese meristem from the vegetative to the floral phase was apparently speeded up by vernalization. It has already been shown in a controlled environment cabinet during the development of a temperature-response model for change in apex diameter (W u r r et al. 1995).

At floral transition, the rate of cell division increased in all meristem zones, as has been reported in other species by Cutter (1970) as well as Cors on and Giff ord (1969). 


\section{CONCLUSIONS}

1. The effect of devernalization on the anatomical structure of the broccoli meristem signifies as early as 6 days and induces retardation in its enlargement and flattening.

2. During transition to flowering the number of tunica layer continuously decreased.

3 . The thermal stimulus plays a role throughout broccoli inflorescence morphogenesis.

\section{Acknowledgements}

This scientific work was financed from the research project UAM - AR PU-II/76 2007-2008.

\section{REFERENCES}

B e s n a rd-Wibaut Ch., 1977. Reponses du meristeme caulinaire a differents types d'induction florale. Ann. Biol. 14(9-10): 386-449.

Björkman T., Pearson J., 1998. High temperature arrest of inflorescence development in broccoli (Brassica oleracea var. italica). J. Exp. Bot. 49: 101-106.

Cutter E.G., 1970. Recent experimental studies of the shoot apex and shoot morphogenesis. Bot. Rev. 3: 7-113.

Corson G.E., Gifford E.M., 1969. Histochemical studies of the shoot apex of Datura stramonium during transition to flowering. Phytomorphology, 19: 189-196.

Fontes M.R., Ozbun J.L., Sadik S., 1967. Influence of temperature on initiation of floral primordial in green sprouting broccoli. Amer. Soc. Hort. Sci. 91: 315-320.

Fujime Y., Okuda N., 1994. Method for prediction of budding and harvest time of broccoli under field condition. Acta Hortic. 371: 355-362.

Fujime Y., Okuda N., 1996. The physiology of flowering in brassicas, especially about cauliflower and broccoli. Acta Hortic. 407: 247-254.

Hejnowicz H., 2002. Anatomia i histogeneza roślin naczyniowych. Państwowe Wydawnictwo Naukowe, Warszawa: 498-533 (in Polish).

Kałużewicz A., Kordakow J., Czosnowski E.

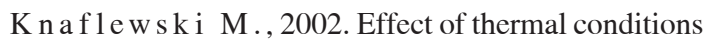
on the initiation of broccoli curd. Wyd. A.R. Wrocław ISSN 1505-0297. Elect. J. Polish Agric. Univ. Hortic. 5(2): 1-9.
Scofield S., Murraya J.A.H., 2006. The evolving concept of the meristem. Plant Molec. Biol. 60: 5-7.

Tan D.K.Y., Birch C.J., Wearing A.H., Rickert K.G., 2000. Predicting broccoli development I. Development is predominantly determined by temperature rather than photoperiod. Sci. Hort. 84: 227-243.

Wurr D.C.E., Feellows J.R., Phelps K., Reade r J., 1995. Vernalisationin calabrese (Brassica oleracea var italica) a model for apex development. J. Exp. Bot. 291:1487-1496.

Veit B ., 2006. Stem cell signalling networks in plants. Plant Molec. Biol. 60: 793-810.

\section{Wpływ dewernalizacji na przejście merystemu pędu brokuła Brassica oleracea var. italica cv. 'Fiesta' $\mathrm{z}$ fazy wegetatywnej $w$ fazę początku kwitnienia}

\section{Streszczenie}

Aby zbadać skutki dewernalizacji (skokowego podwyższenia temperatury po indukcji chłodem) wykonano analizę morfometryczną wierzchołków wzrostu pędu brokuła (B. oleracea var. italica cv. 'Fiesta'). Sadzonki brokuła otrzymane z wysiewu 23 marca 2006 r., po sześciu dniach przepikowano do paletodoniczek wypełnionych substratem torfowym. Do fazy 5 liści sadzonki rosły w fitotronie (temp. $24^{\circ} \mathrm{C}$ ), po czym były wernalizowane (temp. $16^{\circ} \mathrm{C}, 35 \mathrm{dni}$ ) i dewernalizowane (temp. $24^{\circ} \mathrm{C}, 14 \mathrm{dni}$ ). Od 27 maja do 10 czerwca w odstępach 2 dniowych pobierano wierzchołki wzrostu brokuła do analiz. Pomiary morfometryczne wykazały, że dewernalizacja spowodowała zaburzenia w przejściu z fazy wegetatywnej do fazy ewokacji kwitnienia, co przejawiało się w opóźnieniu i rozchwianiu poszerzania i spłaszczania się wierzcholka. Natomiast tendencja do stopniowego redukowania warstw tuniki (w miarę spłaszczania się wierzchołka) nie uległa zmianie.

Rośliny poddane dewernalizacji, chciaż z opóźnieniem, zawiązały pąki kwiatostanowe. Zastosowanie devernalizacji u żadnej rośliny nie spowodowało całkowitego zahamowania rozwoju ‘róży' brokuła. 